\title{
Correction to: Xenobiotica-metabolizing enzymes in the skin of rat, mouse, pig, guinea pig, man, and in human skin models
}

\author{
F. Oesch ${ }^{1} \cdot$ E. Fabian ${ }^{2} \cdot$ Robert Landsiedel ${ }^{2}$
}

Published online: 12 September 2018

(c) The Author(s) 2018

\section{Correction to: Archives of Toxicology (2018) 92:2411-2456 https://doi.org/10.1007/s00204-018-2232-x}

This article is published with the incorrect copyright holder name in the HTML article as "C Springer 2018". The correct copyright line should read "The Author(s) 2018" (as it appears in the article PDF).
Open Access This article is distributed under the terms of the Creative Commons Attribution 4.0 International License (http://creativeco mmons.org/licenses/by/4.0/), which permits unrestricted use, distribution, and reproduction in any medium, provided you give appropriate credit to the original author(s) and the source, provide a link to the Creative Commons license, and indicate if changes were made.

The original article can be found online at https://doi.org/10.1007/ s00204-018-2232-x.

Robert Landsiedel

robert.landsiedel@basf.com

1 Institute of Toxicology, Johannes Gutenberg-University,

Obere Zahlbacherstr. 67, 55131 Mainz, Germany

2 Experimental Toxicology and Ecology, GV/TB, Z470, BASF

SE, Carl-Bosch-Str. 38, 67056 Ludwigshafen, Germany 